\title{
Packaging Differences of News Content on Title
}

\author{
Atiqa Sabardila1, I Dewa Putu Wijana ${ }^{2}$, Suhandano² \\ ${ }^{1}$ Universitas Muhammadiyah Surakarta \\ ${ }^{2}$ Universitas Gadjah Mada \\ Email: Atiqa.Sabardila@ums.ac.id
}

\begin{abstract}
This study investigates anything that underlie the differences of the variation on the packaging variation of the news content on the title that is based on the topicalization, the materials of news title writing, clarity and complexity of the news content, reference shifting from the title to the body of the news, roles of the mediator and the source of the news, maintaining the local value of the news, comparison between the news content on the prior text, and the ideology of the news. The analysis was conducted through pragmatic identity method, referential identity method, and traditional identity method. The data were analyzed by employing discourse approach (: microstructure), especially the connectivity between the title to the body of the news. There are many things that underlie the differences of news content packaging on the straight news. From the structure of the news element, it can be found the several topicalizations such as the topicalization of what, who, where, when, cause, manner, or the combination of two or more elements of the news. A clear and complex package of a news content on the title gives an ease to the reader to understand the news content. However, in a package which does not put the clear reference on the title, the readers are suggested to continue to read the body of the news. Then, in a package which put the source of the news and its utterance on the title, the journalist tries to enclose the relation of the reader to the source of the news. Meanwhile, in a package which put the journalist as the mediator, the readers are invited to understand the content of the news based on their understanding and interpretation. As a commodity, any packages are utilized so that the news papers are not left behind by the readers. In a news which contains local value, the local utterances are maintained for the readers from other area to learn. Finally, in the package of the news content, the selection of the news topics becomes the ideologies which are harmonized with their vision-mission.
\end{abstract}

Keywords: ideology of the news, mediator, packaging of the news content, reference, source of the news, title, topicalization

\section{INTRODUCTION}

The title of a report in a national newspaper in Indonesia should be investigated since the productive and creative data availability. In a productive title, it is possible to describe the stable pattern of the title. Furthermore, the title which is written creatively is possible to be produced several level that will show the characteristic of the linguistic form on the title. Furthermore, journalist shows any attitudes towards the news he/she presented. The result is that it elicits the differences between the content of the news on the title with the content of the news on the body of the news itself. The shifting of this modus is proper to be investigated. Based on the result of the reading, the existence of intervention of the news writer is influential to the variation of the figurative title.

Towards the topic of the same news for example, is there any difference in packaging the content of the news, then what foregrounds the 
similarities and differences the packaging of the content of the news on the title. Since the space is limited, will they decide to choose the news content that is presented on title? Is the utterance from the source of the news elicited at the same time with the speaker? Is there any changing of the act, i.e. changed into the news writer and is the ideology of the newspaper drawn in the option of news topic.

Based on the elaboration, the researcher is interested in doing such research dealing with all the things that foregrounds the differences of the way the writer of the news in presenting the news content on the title. This study is also intended to show the consistency of the national newspapers in developing their own vision and mission, including in pronouncing the local utterance in order to develop the local value itself.

The content of the news is a commodity sold by the journalists in the mass media, printed or online. Therefore, the journalists present it in many ways. One of them is the packaging. Through the reading of the news, the journalists have been proved making the package in the vary content of the news. Through the vary packaging, the journalists want their newspapers are not left behind. The monotonous presentation will always be prevented.

Based on the further reading towards the variation of the news title, the packaging of the content of the news can be investigated in many ways. The importance of identifying the news content is based on the existence of topicalization from the writers based on the phenomena appearing the variation of the elements of the news, $5 \mathrm{~W}+1 \mathrm{H}$. Furthermore, based on the position, the news content can be judged based on the quality of the materials. In packaging the news content, it seems that the journalists also develop the packaging of the clear and complex news title towards its content. The readers are given the summary of the news. The explanation about the reason of the selection of this packaging should be investigated. Meanwhile, in the other packaging, the journalists do not put the clear reference of the news content on the title. Why should the presentations be developed?

The other packaging provides the source of the news and its utterance. Then, the other packaging indicates the roles of the journalists as the mediators. This is the reason why this packaging needs to be developed. Although a news paper is labeled as national newspaper, the local value of the news content is given its portion. What do they expect from the selection of this packaging?

As the presenters of the complete information, they should develop the variation of the packaging of the news content on the continuous news. Does it is done so that the readers want to read the continuous news topic? In the interim, the packaging of the news content can also be practiced towards the selected news topic by considering the ideology of the newspaper.

This current study is expected to contribute: (1) proving that newspaper has not been proper to be left behind since it is successful to develop any functions and educations; (2) proving the significant role of journalist as mediator, i.e. connector between the owner of the information with the information seekers and the significant role of source of the news in uttering the statements in the news title.

Some data of the research can be connected to the idea of priority. The term priority in this research can be described as ordering. The ordering deals with mood of presenting in the different order, especially to the agent. There are not any arbitrary arrangements. However, it is always motivated by the motive and certain interest (Santoso, 2012: 155). The sequence is the part of the element of syntax that can give information about ideology. This case is also connected to the critical linguistics. In communication such as newspaper, language is used to serve speaker's certain goal. Therefore, there is a power. According to Fowler (1985: 61), power is a person's ability or institution in restraining or controlling other people's attitude and material life. Power means the relation between "the owner of the power" and "the being powered".

In accordance to the idea of power, Fairclaugh (1995:1) gives limitation that conceptually, power has two meanings: (1) un-symmetric relation within participants in the discourse events and (2) un-equivalent capacity or ability in controlling how a text is produced, distributed, and consumed in the context of social. Through organizing the element 
of the clause filler, it proves the existence of power. According to Fairclaugh (1995: 2), the use of language to the social practice is done through the options of word, metaphor, grammatical, preposition and implicature, convention of politeness, turn-taking, generic structure, or style of utterance.

According to Fairclaugh (1989), the content of ideology in discourse, especially language, is expressed through these lingual form (i) transitivity, (ii) active-passive sentence, (iii) negative-positive sentence, (iv) declarative-interrogative-imperative sentence, (v) relational modality, (vi) personal pronominal, and (vii) expressive modality.

Packaging the information in the clause level becomes Folley's (2007) focus. Packaging can be word order, verbal form, preposition marker shift, displacement, topic-comment construction, argument structure, verbal adjustment, or activepassive construction.

Halliday (1985) introduces three functions of language, i.e. ideational, interpersonal, and textual. The function of ideational is used to express experience. There are two things related to this representation, i.e. experiential meaning that codes experience and logical meaning that shows relations or connections the element based on logic, such as the relation subject-predicatecomplement, main-modifier, and relations in word organization, such as conjunction. Function of interpersonal is used to code the interaction, showing how the attitude stays, proposes, codes about the obligation and tendency and expresses attitudes. Function of textual is used to organize experiences, logical meanings and interpersonal into a coherence dealing with verbal and written language.

The first function deals with the meaning which explains human experience. If it is applied in this current research, that function relates with anything which are written by journalist. The second function, interpersonal, is used to determine and maintain the social relation. Therefore, this function deals with the relation between the provider of the information (: journalist) with the receiver of the information (: reader). The third function, textual, is used to perceive the discourse. This function deals with the equipment that the journalist is used to communicate: text. In this context, the function refers to the news discourse and the divisions (such as title and the body of the discourse and also picture or photo).

Through the function of ideational, it can be identified the variation of the news content on title; through the function of interpersonal, it can be identified the appearance of the indirect communication between sender of the news (journalist) to the receiver of the news (reader); and through the textual function, it can be presented any grammatical units (word, phrase, clause, and sentence) on the title of the news. In applying the interpersonal function in writing the title, the sender of the news builds certain communication to the reader.

Furthermore, Folley (2007: 362-446) explained the typology about packaging the information in the structure of clause. One of them is presented with the topicality. The cases of writing title in five newspapers are developed in clause, variation of clause pattern and the following level on the title proves the existence of topicality itself.

The process of writing the title of the news produces word, phrase, clause, or group of clause. After becoming a title, the existence of word, phrase, clause, or the group of clause can be intended as meaning that is correlated to the body of the news. In addition, in building title there are several things to take into account such as ellipsis, shift, reference, etc. Through the evidence of several processes, it can be concluded that title has closely relation with the body of the news.

\section{RESEARCH METHOD}

This current study belongs to descriptive research that describes linguistic phenomena that appears on national newspaper. The objects of this research are word, phrase, and clause on the title of news and also the reference that is referred by word, phrase, or clause in the title. The referred reference is connected to the element of the news on the formula $5 \mathrm{~W}+1 \mathrm{H}$ (: who, what, where, when, why, and how).

The data sources are random chosen national newspaper. The results are Jawa Pos (JP), Kompas $(K)$, Koran Tempo (KT), Media Indonesia (MI), and Republika $(R)$. The data were taken during 1 year (2014) that were started Januar $1^{\text {st }}$ - December 
$31^{\text {st }} 2014$. The current study chooses straight news that presents facts objectively based on the element of $5 \mathrm{~W}+1 \mathrm{H}$ that were appeared on the front page or last page. The columns that were investigated are news that can cover the national news, regional, international, sports, science, and education.

The data of the present research is in the form of titles of the news. The data context is sentences on the lead or the body of the news that have closely connection with the title building, overall discourse on the body of the news, reference of the title, picture that completes the news discourse, and also the sub-title.

Eliciting things that foregrounds the appearance of the variation of the packaging of the news content is done by these techniques: (1) referential identity technique, i.e (a) identifying the element of the news that acts as filler of the title and (b) material of the news that is identified based on the classification of opinion and fact, (2) read marker-technique i.e (a) identifying word, phrase, or clause that fills the front position in the title structure and (b) with the body of the news, (3) translational identity technique i.e. identifying the origin of the word that has local value so it is selected to fill the title, and (4) pragmatic identity technique i.e. identifying the source of the news that produce utterance on the title. Furthermore, the distributional method by the use of paraphrase technique is employed to analyze the data found. This technique is also utilized to highlight the meaning of the title.

The result then is presented in the form of formal presentation, i.e. formulating by the code and symbols, and non-formal presentation, i.e. formulating by the common word (Sudaryanto, 1993: 145).

\section{RESULT AND DISCUSSION}

\section{Topicalization}

The element of a report $(5 \mathrm{~W}+1 \mathrm{H})$ becomes a focus in the case of topicalization. When an element is preferred, the existence has character, i.e. appears independently or appears with the other components.

The element of who can emerge independently. It can also be a partner to the element of what. Two references on the element of who, i.e. (1) it refers to figure, and (2) it refers to society. The figure reference is explained with the statement of name, position, position that is completed with personal name, and title.

Because of the intensity of appearance on the title, the element of who that refers to Indonesian Corruption Eradiction Commission is explained specifically. Through the couple of who + what, it is identified all those activities in the institution, such as confiscation, tracking, investigation about the other bandage, estimation, the investigation towards the deviation, picking up witness, forbidding suspect to go abroad (to the ease of investigating), guarding in using fund, prevention, frisking, etc.

(1) "KPK Sudah Sita Aset Chaeri" (KT,28/1/2014)

'Corruption Eradiction Commission (KPK) Has seized Chaeri's Assets’

(2) "KPK Lacak Harta Chaeri dan Airin" (KT, 28/1/2014)

'Corruption Eradiction Commission (KPK) Tracks Chaeri's and Airin's Assets'

(3) "KPK Usut Keterlibatan Kaban dan Suswono" (KT, 1/2/2014)

"Corruption Eradiction Commission (KPK) Handles the Kaban and Suswono's Mix Up'

(4) "KPK Temukan Penyimpangan Dana Haji” (JP, 7/2/2014)

'Corruption Eradiction Commission (KPK)FindsDivergenceinHajjFunding'

(5) "KPK Jemput Kasir Atut" ( $K, 8 / 2 / 2014)$ 'Corruption Eradiction Commission (KPK) Picks Atut's Chasier Up'

(6) "KPK Larang M.S. Kaban ke LN" (JP, $12 / 2 / 2014$ )

'Corruption Eradiction Commission (KPK)ForbitsM.SKabantoGoAbroad'

(7) "KPK Kawal Dana Jaminan Kesehatan Rp 40 Triliun" (KT, 12/2/2014) 
'Corruption Eradiction Commission (KPK) Watches the Health Insurance Funding IDR 40 Billion'

Title that prefers the element of what appears in $(8)-(10)$

(8) “Usut Pemberian Wawan" $(K, 14 / 2 / 2014)$

'Handling Wawan's Gift'

(9) "Usut Peran M.S. Kaban lewat Sopir" (JP, 14/2/2014)

'Handling the Role of M.S. Kaban through His Driver'

(10) “Usut Semua Penyuap Akil" (MI, $22 / 2 / 2014)$

'Handling All Bribes of Akil'

If the above titles belong to figure that work suitably with the profession or act they hold, so the people that are reported from the following titles belong to figure who get in touch with the case.

(11) "Kalla Dipanggil Bersaksi Pekan Depan” (KT, 3/6/2014)

'Kalla is Invited to Witness Next Week'

(12) "Kaban Dicegah ke Luar Negeri” (BI, $13 / 2 / 2014$ )

'Kaban is Prohibited to Go Abroad'

(13) "Kadishub-Kadispendik Dicopot" (JP, $13 / 2 / 2014$ )

'Head of Department of TransportationHead of Education Department is fired'

(14) "Sutan Bhatoegna Dicegah ke LN" (JP, $14 / 2 / 2014$ )

'Sutan Bhatoegana is Probibited to Go Abroad'

(15) "Putra Menkop-UKM Tersangka" ( $R$, $17 / 5 / 2014$ )

'Son of Coordinating Minister for Cooperatives-Small and Medium Enterprises Suspects'
Functionaries who are in the case of corruption become people's interest. The functionaries are written by their personal names, position in their institution, status in their family, and status in their own family who are added with the position of their own parents.

Revealing the mixing up of the functionaries in corruption becomes interesting to the journalist.

The element of who origins from people that stated by mentioning, such as example (16) - (20), i.e. consumer ..., hiker ..., victims ..., the refugee ...

(16) "Konsumen Pedagang Kaki Lima Diancam Denda Rp 1 Juta" (KT, 28/1/2014)

'Consumer of Street Vendors are Threated to be Punished IDR 1 Million'

(17) "Pendaki Welirang Tewas karena Kedinginan" (KT, 28/1/2014)

'Welirang climbers killed because Chills'

(18) "Tujuh Korban Longsor di Jombang Masih Dicari" (K, 29/1/2014)

'Seven Victims of Landslide in Jombang Still Sought'

(19) "Mereka Berkorban untuk Demokrasi" (K, 2/2/2014)

'They Sacrifice for Democracy'

(20) "Pengungsi dari 16 Desa Dipulangkan" $(R, 3 / 2 / 2014)$

'Refugees from 16 Villages are Repatriated'

If the overall character in title that has core element of who, then it is found these pairs: (a) who (independent), (b) who + what, (c) who + what + when, (d) who + what + why, (e) who + what + where, (f) who + what + how many, (g) who + what + what and (h) who + what, who + what.

The element of who refers to the figure and people; while the element of what refers to act and result. Those which refer to acts are begun by verb and the variation. Those who refer to the results are the selection of noun/noun phrase.

In accordance to the corruption removal that becomes a big issue in Indonesia now days, the topicalization about the figure of KPK is 
intensively reported than its activity. Then, the performance of KPK is much more intensively stated as a title compared to the activity, such as (20) - (22).

(21) "Harta Wawan Mengalir ke Anggota DPRD Banten" (JP, 11/2/2014)

'Wawan's Assets Flow to Assembly Members of Banten'

(22) "Soal Atut, Airin Diperiksa 11 Jam" (JP, $12 / 2 / 2014$ )

'Related to Atut, Airin is interrogated 11 Hours'

(23) "Dana Haji Dipakai Beli Mercedes" (KT, 13/2/2014)

"Hajj Funding is Used to Buy Marcedes'

The results of the patterns of pairs on the element of what on title are (a) what (example (23)), (b) what, what (24), (c) what + where (25), (d) what + how (26), and (h) what, what (then) what (27).

(24) "Sokong Kepemimpinan Lokal" ( $K$, 29/1/2014)

'Chock Local Leadership'

(25) "Diperiksa 9 Jam, Dicecar 70 Pertanyaan" (JP, 25/2/2014)

'Being Interrogated for 9 Hours with 70 Questions'

(26) "Waspadai Dampak Cuaca di Timur" $(K$, 28/1/2014)

'Beware of the Impact of Weather in the East'

(27) "Usut Peran M.S. Kaban lewat Sopir" $(J P, 14 / 2 / 2014)$

'Investigate the Role of M.S Kaban through His Driver'

(28) "Minta Dikerok, Batuk-Batuk lalu Pingsan" (JP, 2/2/2014)

'Ask to be Scrapped, Cough then fainting'

In addition, the element of where forms several pairs: (a) where + who + what (28) and (b) where + what (29).
(29) "Di Kementerian ESDM KPK Sita Rp 2 Miliar" (MI, 8/2/2014)

'In The Ministry of Energy and Mineral Resources, Corruption Eradication Commission Impounds 2 Billion'

(30) "Di Medsos, JKW-JK Ungguli PrabowoHatta" $(K, 7 / 7 / 2014)$

'In the Social Media, JKW-JK Excels Prabowo-Hatta'

An area refers to region (province, regency, city) (Kamus Besar Bahasa Indonesia, 2007: 948). In this explanation, the meaning of region can be broader anymore. In the analyzed title of news, there is no relation with the topicalization of the element of where, prepositional phrase refers to a concrete place, such as clinic, ship, Maluku, Bandung, Afghanistan, Jombang, Pantura, MK (Court of Constitution).

(31) "Di Kota Besar Ini, Hak Anak Terus Terampas" $(K, 7 / 5 / 2014)$ 'In this Big City, Robbed of Children's Rights Continues'

Then, the element of when that builds pairs (a) when, (b) when + what, (c) when + who + what, and (d) when + what, when + what . The followings are the title which prefers the element of when. In the example (31) - (35), the element of when appears independently.

(32) "Ketika Binatang Ditukar Innova" (KT, 3/2/2014)

'When an Animal Exchanged to Innova'

(33) "Ketika Pasien Takut Dibuang Rumah Sakit ..." (K, 11/2/2014)

'When Medical Patient is Afraid of Being Expelled by Hospital'

(34) "Saat Satu Miliar Interaksi Terjadi di Facebook" (K, 2/6/2014)

'When a Billion Interactions Occur in Facebook'

(35) "Setelah Semua Usaha Terbaik Dilakukan ..." (K, 26/7/2014)

'After All Best Efforts are Done' 
(36) "Saat Delegasi Gagal Masuk Gaza" (K, 26/9/2014)

'When the Delegation is Failed to Enter Gaza'

Example (36), the element of when appears with the element of what. Example (37) the element of when pairs to what in the plural clause.

(37) "Minggu ini Ada Tersangka Kasus Haji" (MI, 21/5/2014)

'This Week There Will be a Suspect in the Case of Hajj'

(38) "Siang Pensiun, Sore Tersangka" (JP, 22/4/2014)

'Afternoon retired, Evening Suspect'

The topicalization of the element of when is in the form of time, day, week, month, year, or other time related to the running of activity or event.

On the example (38), the element of why appears in pair with the element of what. Example (39) and (40), the element of why is in pair to the who + what.

(39) "Karena Asap, Maskapai Rugi Miliaran Rupiah" (KT, 12/10/2014)

'Due to Smoke, Airplane Enterprise Suffers a Financial Loss'

(40) "Terlilit Utang, Ayah Tikam Anak dan Istri” $(K T, 1 / 2 / 2014)$

'Having a Debt, a Father Kills His Child and Wife'

(41) "Tersandung Plagiat, Anggito Mundur dari UGM" (JP, 18/2/2014)

'Due To Plagiarism, Anggito Retreats from UGM'

There is a correlation of cause-effect on title, i.e. (karena) asap (mengakibatkan) rugi. The title puts forward the element of why appears on (41) $-(42)$.

(42) "Tidak Banyak Kemajuan, Brahimi Kecewa" $(K, 29 / 1 / 2014)$

'There are not Many Improvements, Brahimi is Dissapointed'

(43) "Tersandung Plagiat, Anggito Mundur dari UGM" $(J P, 18 / 2 / 2014)$

'Due to Plagiarism, Anggito Retreats from UGM'

Based on the analyzed example, Baryadi (2007) found that minor clause which in the left of the primary clause contains old information. Since, the level that is analyzed is in the form of discourse, the minor clause is related to the information contained in the previous is relevant. Clause that is on the left of primary clause in the title does not mix up the clause or other sentences outside the title, except the clause that forms title at the same time. The mixing up clause and other sentences are done to explain the process of title formation.

Kesuma (2005) found that the function of $K$ (: keterangan 'adverb') categorically, i.e. can be located adverbial, phrase, prepositional phrase, and additional clause. One of the findings is the systematic function of $\mathrm{K}$ is causal. If the act of the causal is preferred, it will fill the front position. The identification of $K$ as the element of why in the title appears independently as the title of the news.

The element of how appears in (43). The title (43) can answer the question "how long does (Narti) wait (example Presiden Susilo Bambang Yudhoyono)? and "how long does (she: Narti) meet?

(44) "9 Jam Menunggu, Ditemui 10 Menit" $(K T, 18 / 2 / 2014)$

' 9 Hours Waiting, Ten Minutes Meet'

\section{Materials of News Title Writing}

A report should be investigated from the source of the news. A news source is person or institution that gives information as the material in writing a news (Junaedhie, 1991: 252). Journalist should write the fact in delivering news. By writing the fact, whoever the journalist is, when he/she reports something, journalist will produce the same information: objective.

The fact is elicited from any news source. However, in presenting title, it is not all collected fact becoming title. The writer of the news is the one who has authority in deciding the fact. In this part, the fact will be sorted between fact from a source of the news and the fact that belongs to summary from some sources of the news. This 
clarification is important to the readers since they will grasp information about title so they can have a critical thinking.

The following examples explain the development of the case dealing with Legislative Election in Court of Constitution, i.e. the case increases 767. Newspaper $J P, M I$, and $R$ write in the body of the news with the same count (767). After it is packed on title, each of the newspaper decides the different editorials.

(45) "Perkara Pileg di MK Naik Jadi 767" $(J P, 17 / 5 / 2014)$

'Lawsuit of Legislative Election in MK (Constitution Court) Increases to 767'

(46) "MK Terima Aduan 767 Perkara Pemilu" (MI, 17/5/2014)

'MK (Constitution Court) Receives 767 Complaints about Legislative Election Cases'

(47) "Jumlah Perkara di Mahkamah Konstitusi Meningkat" (R, 17/5/2014)

'The Number of Cases in MK (Constitution Court) Increases'

The objectivity of the news on each newspaper can be tested by looking at the utterance on the body of the news. Title (44) needs the news content that presents explanation about the comparison of the case of Legislative Election that comes into MK, i.e. previously some cases increase to 767 cases. The last case is explicitly stated on the title (44). The news source does not always refer to personal. In (44) the source of the news is MK (court of constitution).

Quotation (44a) is relevant to what is needed in title (44) above. There is an important explanation, i.e. 702 cases increase to 767 cases and the increasing is known after investigating application documents.

(44a)"Jumlah perkara sengketa hasil Pemilihan Umum Legislatif (pileg) 2014 yang ditangani Mahkamah Konstitusi (MK) naik dari 702 perkara menjadi 767 perkara. Kenaikan ini diketahui setelah MK meneliti berkas permohonan dan petitum pemohon, yaitu terdapat 767 daerah pemilihan (dapil) yang dipersoalkan peserta pemilu." $(J P$, $17 / 5 / 2014)$

'The number of cases of the result of legislative election (2014) that is handled by MK (Constitution Court) increases from 702 cases to 767 cases. This increasing known after the Constitution Court observes the application document, i.e. there are 767 election area that is questioned by the participants of the election'

It will be different if the title (44) is inserted with passive verb diperkirakan, such as (44b).

(44b)"Perkara Pileg di MK Diperkirakan Naik Jadi 767"

'The Case of Legislative Election in Constitution Court is Estimated to Increase to be $767^{\prime}$

Eventhough after it is investigated, i.e. 767 cases, by appearing the passive verb diperkirakan, the written information then it is marked based on estimation.

From the title reading, it can be sorted between opinion from a source of the news and the summary from some sources. Example (47) contains opinion.

(47) "Boediono Layak Tersangka" (MI, $10 / 2 / 2014)$

'Boediono is Proper to be a Suspect'

In order to prove that opinion exists in the title, it should be based on this following quotation.

(47a) “... pada Budi Mulya dan Pak Boediono. Fakta persidangan sudah sangat pantas untuk menaikkan status tersangka bagi Pak Boediono, "kata ... Muhammad Misbakhun, di Jakarta, kemarin." (MI, 10/5/2014).

'... to Budi Mulya and Pak Boediono. The court fact has been proper to make Pak Boediono suspect, 'says Muhammad Misbakhun, in Jakarta, yesterday.'

Since it contains an opinion, if it is tracked, it can be identified the source of the news. So, the variation $(47 b)$ is the origin of the utterance. 
(47b)"Misbakhun Munir: Boediono Layak Tersangka"

'Misbakhun Munir: Boediono is Proper to be a Suspect

\section{Clarity and Complexity of News Content}

The clarity of the news content is when the readers can understand the content of the news without reading the explanation of the body of the news. Furthermore, the complexity of a news is when the title presents a set of pair, such as who + what, who + what or the presence of the element of plural what, such as what + what + what .

The writer of a news selects title (48) - (53) to pursue the readers concentrating on the part of the title since it appears the limitation of time to read. Thing that is topicalized by the writer has been summarized on title.

(48) "Wawan Ngaku Sakit Mag, Anas Keluhkan Sakit Gigi” (JP, 27/2/2014)

'Wawan Says He is Stomachache, Anas Says He is Toothache'

(49) "Berbiaya Murah, Nyaman, dan Aman" (K, 6/6/2014)

'Cheap, Comfortabel and Safe'

(50) "Jokowi Kumpulkan Tim, Prabowo Persiapan Psikis” (KT, 15/6/2014)

'Jokowi collects His Team, Prabowo Prepares for Psychological'

Two clauses on each title show the core of the news on each discourse. Writer intends to insert two cores of the news. It is possible for other writers to write two core clauses on each title that are not placed equally, so the writer only selects one clause. The followings are the alternative title (48) $-(53)$.

(48a)"Wawan Ngaku Sakit Mag"

"Wawan Says He is Stomachache

(48b)“Anas Keluhkan Sakit Gigi”

'Anas Says He is Toothache'

(49a) "Berbiaya Murah ...

'Cheap Cost ...'
(49b)"Nyaman ..."

'Comfortable ...'

(50a)"Jokowi Kumpulkan Tim" 'Jokowi Collects His Team'

(50b)"Prabowo Persiapan Psikis" 'Prabowo Prepares His Psychological'

(51b) "Jokowi Tonjolkan Bukti" 'Jokowi Emphasizes Evidence'

(52a) "Prabowo Utamakan Pertanian" 'Prabowo Prioritizes Farming'

(52b) “Jokowi Utamakan Pertumbuhan" 'Jokowi Prioritizes Growth'

(53a) "Prabowo Tawarkan Berdikari" 'Prabowo Offers Self-Reliance'

(53b)"Prabowo Bagikan Uang ke Desa" 'Prabowo Distributes Money to Villages'

Pattern (48a) - (53b) is acoorant to (54) and (55).

(54) "Jokowi-Kalla Banyak Mendapat Serangan” (KT, 7/6/2014)

'Jokowi-Kalla Get a Lot of Attack'

(55) “Jokowi Lebih Konkret” (MI, 16/6/2014) 'Jokowi is More Concrete'

On title (56) the writer of the news shifts the core utterance to the title.

(56) "Muncul, Menang, dan Meredup" (K, $18 / 5 / 2014)$

'Appears, Wins, and Extinguishes'

By connecting the minor title, i.e. "Partai Demokrat" which is placed on the previous title "Muncul, Menang, and Meredup", the content of the news in the body of the news has been represented. If the minor title and the title itself are turned into paraphrase, it will produce this structure "Partai Demokrat Muncul, (Partai Demokrat) Menang, and (Partai Demokrat) Meredup" or it can be "Partai Demokrat Muncul, Menang, dan Meredup". 
In order to know whether the content of the news on title is represented the whole news content on the body of the news, it needs reading so that there is no mistakes in concluding.

\section{Reference Shift to the Body of the News}

On (57) and (58) readers do not get the content of the important report when they read the title only. There is a journalist's intention to hide the content of the news in the body of the news itself.

In order to give direction to the body of the news, it means that the success of the news writing depends on the reader's interest to do what is intended, i.e. enjoying the reading in the body of the news.

(57)“Mereka Hanya Tahu Rhoma Irama” ( $K$, 25/3/2014)

'They Only Know Rhoma Irama'

(58)“Mereka yang Melaporkan Hadiah” (KT, 22/3/2014)

'They Report Prices'

The pronoun mereka on (57) will answer the reference through the following quotation:

(a) "Hiruk-pikuk perhelatan kampanye menjelang pemilihan legislatif April mendatang tak singgah di lokasi pengungsian warga Syiah," (b) "Ratusan pengungsi di Rumah Susun Jemondo, Puspa Agro, ... nyaris tak tersentuh kedatangan knalpot sepeda motor dan teriakan calon legislator menjajakan janji-janjinya," (c) "Anwar bersama ratusan warga Syiah lainnya menghuni Rumah Susun itu sejak Juni lalu lantaran konflik aliran dalam Islam di kampung mereka di Sampang Madura", ... yakni Rhoma Irama, si raja dangdut" (K, 25/3/2014). Therefore, mereka refers to warga Syiah (: ratusan pengungsi di Rumah Susun Jemondo, ..., Anwar bersama ratusan warga Syiah lainnya, atau Anwar dan para pengungsi).

'The crowd of campaign of legislative election in the next April does not visit the refugees of Syiah', (b) 'Hundreds refugees in Jemondo, Puspo Agro, ... is almost untouched by the people who are campaigning for legislative election,' (c) 'Anwar and the hundreds refugees of Syiah live in the house since June due to the conflict of religion in their village in Sampang, Madura' ... Rhoma Irama, the King of Dangdut' $(K, 25 / 3 / 2014)$.

The rereference (57) can be elaborated to these variations (57a) and (57b).

(57a) "Warga Syiah Pengungsian Hanya Tahu Rhoma Irama"

'Refugees of Syiah Only Know Rhoma Irama'

(57b) "Pengungsi Syiah di Rusun Jemondo Hanya Kenal Rhoma”

'Refugees Syiah in Jemondo Only Recognize Rhoma'

There is a shift of interest in presentation (57a) and (57b), i.e. from the body to the title of the news. If the readers read the title only, they will directly get the clarity.

From the use of pronoun at the beginning, it can be concluded that the un-clarity of the title is intended to do by the writer of the news to give power on the body of the news, i.e. answering the un-clarity on title due to the abundant of omission, shift, or other processes.

The body of the news saves reference. The location of body of the news is after pronoun on title. Therefore, it creates the correlation between the title and the body of the news cataphorically.

It is stressed that the pronoun on title which makes un-clarity can be interesting for the reader to continue their reading to the body of the news.

\section{Roles of Mediator and Sources of the News}

Diction perceives whether or not the utterance is directly stated from the source of the news. In order to note a direct utterance, it is usually used a first person pronoun, whether single or plural. Besides, it also elicits the source of the news. Then, the indirect utterance perceives the use of third person pronoun, whether in the form of single or plural. If it uses these pronouns, therefore, the title will elicit the name. The followings are the examples. 
(58) "Rektor Unsrat: Laporkan jika Saya Korupsi” $(K, 1 / 3 / 2014)$

'Rector Unsrat: Report if I Corrupt'

(59) “Bagi Saya itu Pasal Gila” (MI, 1/3/2014) 'For me, That's a Crazy Article'

(60) "Mati, Pak Jaksa? Ini Pakai yang Punya Saya" (MI, 3/5/2014)

'Dead, Presecutor? Use Mine'

Title (58) - (60) originates from the source of the news that is interviewed by the journalist. It is shown by the relevance of the utterance on title with the utterance in the body of the news that is written by each journalist.

In order to give power to the title, the writer of the news explores the use of language. For example, using a title of a song, verse or lyrics of the song, etc. title (61) - (64) show that case. The writer of the title can create by using substituting technique, such as coconut to santan (milk squeezed from coconut).

(61) "Rayuan Pulau Santan" (K, 30/8/2013) 'Flattery of Santan Island'

A direct utterance in the title of the news is similar to the direct discourse in literature. The writer motive in using direct discourse is in order to strengthen the impression of real or building the similarities with the real thing (verisilitude) and to increase the variation of a text.

(62) "Keretaku Tak Berhenti Lama" (KT, $14 / 3 / 2014$ )

'My Train Does Not Stay Long'

(63) "Terlalu Manis untuk Dilupakan" (KT, $16 / 3 / 2014$ )

'Too Sweet to Be Fogotten'

(64) “Bento, Bento, Bento ..." (K, 9/11/2014) 'Bento, Bento, Bento ...'

The study of prior text has been investigated by Kadarisman (2005) about cultural maxim, i.e. the aspects or cultural value that is appreciated by people. The values are in the forms of good words, literary work, or legend that become "reference" or prior text that can give understanding by listener or reader. The recognizing the topic through reader understanding about the prior text will facilitate them in understanding new thing.

The result of the description of the title of the news emphasizes the source of the news is also shown by interjection. Rolyna (2012) and Hardiah (2012) found the interjections that marked the variant of the Indonesian language informant, i.e. ah, eh, dong, kan, kek, kok, lah, sih, and ya.

Some titles use the interjections that marked by non-formal situation and the presence of the act of the news source by journalist. Furthermore, Hardiah's findings show that the multifunction of interjection, i.e. expressing the feeling, opening conversation, or changing topic. The followings are the title that topicalized utterance from the news source.

(65) "Madura, Ya, Begitu Itulah ..." $(K$, 16/7/2014)

'Madura, Ya, This is it...'

(66) “Duh, Weteng Rasane Mules ...” (KT, 28/11/2014)

'Ouch, Stomachache...'

\section{Maintaining Local Value of News Content}

There is a local value that becomes the writer's concern. The revealer of the value is the form of the use of vocabulary or certain utterance, such as culture.

The writer of the news is the mediator that acts to connect the source of the news to the reader. Vocabulary from the source of the news can be introduced to the society. The followings are the example.

(67) "Jaga Tradisi Tenongan. Potong 70 Ekor Kambing" $(R S, 24 / 8 / 2014)$

'Keep Tenongan Tradition. Slaughter 70 Goats'

(68) “Memedi Sawah', Kearifan Lokal Mengusir Hama" (KR, 22/9/2014) 'Memedi Sawah, Local Value to Expel Plant Deseases'

(69) "Menang Ora Umuk Kalah Ora Mabuk" $(J P, 6 / 7 / 2014)$

'Someone Should be Tough in Facing a Competition, Whether He/She Wins or Loses' 
The utterance that contains local value is taken without any translation of the vocabulary. The three utterances originate from Javanese culture. Tradisi Tenongan is something like cleaning the village from invisible bad thing that is done by people in Pokak, Ceper, Klaten with bringin tenong that contains any prestigious foods in order to build relation within society, then it is brought to Sendang Sinongka. Memedi Sawah is actually a local value in the relation of farmers in order to expel plant disease without damaging sphere.

The utterance "Menang Ora Umuk, Kalah Ora Mabuk" appears in order to heal anybody who is waiting for competition. The statement is closely related to the attitude of waiting for competition, in this case, the presidential election. It is needed a good manner and tough mentality in order to be sincere and introspect themselves when they lose. Those values become provisions for those who are competing. Those values need to be familiarized, according to $J P$.

Giving portion to the culture in Indonesia in reporting means that there is socialization about the introducing vocabulary related to culture. It is not only about the vocabulary mastery, but also there is a transfer of value to the reader so they can learn from the success of "taking care" of the local value from the supporter of the local value itself. It can be a model in searching solution from each district by behaving dynamically. It is in accordance to Sutrisno's statement that culture contains an ethic in having nation. The other form of the ethic is like a willing to give each other. In order to propose the act, it needs a behavior and local value. Local values then is processed to the national value that can be directed and answer the global value $(K$, 3/6/2014).

\section{Comparison Between the News Content on the Previous Text}

Through (70) - (73) the researcher explains that the writer of $J P$ is creative in presenting the title towards the topic of the same news, i.e. S(urya) D(arma) A(li) as the suspect in holding Hajj in 2012. JP, for example, reports the cases several times.

(70) "Setoran Haji Jerat Menag SDA" (JP, 23/5/2014)
'The Stored Commodity of Hajj Snates SDA'

(71) "Prabowo Kaget Penetapan SDA Tersangka" ( $J P, 23 / 5 / 2014)$

Prabowo is Shock of SDA's Suspect'

(72) "KPK Sita Ponsel Dirjen Haji" (JP, $26 / 5 / 2014)$

'KPK Seizes Directorate General of Hajj's Cell-Phone'

(73) "Nasruddin Umar, Salah Seorang Calon Pengganti SDA" (JP,26/5/2014)

'Nasrudin Umar, One of Candidates to Substitute SDA'

The differences of the content of the news on title have an impact on the raising of readers' knowledge about the case faced by SDA. By presenting the in-depth report, the presented news will compete with the actual news.

\section{Newspaper's Ideology}

A topic related to Gita Wirjawan retreat, former Ministry of Trade, from Cabinet, signs a vary functions of report. First, the reporter behaves it by stating an ironical statement; second the reporter behaves it neutrally; and the third behaves it negatively. The retreating is reported in the followings four newspapers.

(74) "Anggap Ikut Konvensi Lebih Mulia" (JP, 1/2/2014)

'Think to Follow Convention is More Noble'

"Gita Mundur dari Menteri saat kasus Impor Beras Memanas" (Subtitle)

'Gita Retreats from Ministry When the Case of Rice Import is Problematic'

"ETIKA PEJABAT"

'Ethics of Officer'

(75) "Gita Wirjawan Tinggalkan Kabinet" $(K, 1 / 2 / 2014)$

'Gita Wirjawan Leaves Cabinet'

(76) "Gita Telat Mundur" (MI, 1/2/2014)

'Gita is Late to Retreat' 
(77) 'Tinggalkan Kabinet $(R, 1 / 2 / 2014)$ 'Leave the Cabinet'

Each newspaper can be described as the sources of the news which are called. There are seven interviewees that were called by $J P$, i.e. Gita Wirjawan, Daniel S., Vice Chief of IV Commission in People's Representative Council, General Secretary of PPP, spokesperson of Demokrat Party (Ihsan Mojo), Dahlan Iskan, and Marzuki Alie. There are seven interviewees of $K$, i.e. Gita Wiryawan, Dahlan Iskan, Marzuki Alie, Rully Charis, and Dien Syamsuddin. If the news topic (functionary ethic) and the title ("Gita Wirjawan Tinggalkan Kabinet" "Gita Wirjawan left the cabinet') are united, it results a paraphrase such as (demi tegaknya) etika pejabat, Gita Wirjawan meninggalkan kabinet '(due to) the functionaries ethic, Gita Wirjawan left the cabinet'. The impression of the structure is formal. Newspaper $K$ stands to be neutral. Furthermore, the attitude is proved by eliciting the news topic: etika pejabat 'functionary ethic'

There are eight interviewees of $M I$, i.e. Gita Wirjawan, Gun Gun Haryanto, Hanta Yuda, Airlangga Hartarto, Firman S., Bambang Soesatyo, Rizal Ramli, dan Bayu Kisnamurti. This identification is important to track the utterance in the title. Is that the word telat (late) originates from interviewee or the journalist? Apparently, the journalist concludes the statement of interviewee. The opinion of telat mundur (late to retreat) originates from them. The conclusion originates from the statement of Gun Gun Haryanto, Hanta Yudha, Airlangga Hartanto and so on that all of them can be tracked in the body of the news.

$M I$ writes a statement that comes from a politician. There is a motive that is stated by $M I$, i.e. whoever the person who is occupying and decides to retreat - not due to a case - is not a good idea, since there is still a problem. Furthermore, the retreat for an officer that will concentrate to a convention, judged as has a good willingness and ethics. This such officer is legal according to the president, Susilo Bambang Yudhoyono (SBY). The officer is judged as giving a good model to the other officer who wants to join to a convention.

There are similarities in those four newspapers about the case. All discourses are completed with a photograph of Gita. His photograph in $J P$ can substitute the element of subject. The photograph of Gita in $K$ acts as complement, and it does not substitute any utterance. However, the photograph that is presented in $R$ can substitute the omitted subject.

$J P$ follows the opinion proposed by Gita that follows the congress is better than staying in the cabinet. The $J P$ report about Gita does not influence the reader, since the retreat of Gita from the cabinet gets permission from the President. However, the utterance anggap ikut konvensi lebih mulia belongs to an opinion from the journalist since the body of the news is not found that statement. The content of the utterance that appears is about the willingness of Gita to be more focus on following the stages of presidential convention. Is the utterance lebih focus is synonymous with lebih mulia? The statement lebih mulia seems cannot be determined the meaning unilaterally. It is different to the utterance lebih fokus that can be subjective. Magnificence is universal value. For statesmen, doing their job in accordance to the oath they take is better than the individual self-interest. $J P$ presents the subtitle "Gita Mundur dari Menteri saat kasus Impor Beras Memanas". Through that subtitle, $J P$ signs that he when there is a case belongs to immoral attitude.

Newspaper $K$ and $R$ are in the middle-of-theroad, since they indicate utterance meninggalkan cabinet (leaving cabinet). $K$ and $R$ have similarity in choosing diction, especially the filler of object predicate (: tinggalkan cabinet). MI gives judgment that the Gita's retreat is late. Hence, MI gives negative judgment. It is based on the source of the news that is interviewed. The intended statements are " ... pengunduran diri Gita di tengah belum beresnya kasus beras impor ilegal dari Vietnam yang masuk ke Indonesia" and "... Gita lari dari tanggung jawab." Does the title prove that $M I$ has bravery to be different? $M I$ has a simple language, i.e. direct and to the point.

However, $K$ and $R$ is more neutral. Those two newspapers select meninggalkan (leave). It can be concluded that MI foregrounds the conclusion from Gun Gun Haryanto, Hanta Yuda, Airlangga Hartanto, Firman Soebagyo, and Bambang Soesatyo that all of them can be trancked in the body of the news. 


\section{CONCLUSION}

Based on the explanation above, this study concludes that there are many things that underlie the differences of the news content packaging of the straight news. Through the structure of the element of the news, this study noted the topicalization, such as what, who, where, when, causality, manner, or the combination of two or more of the element of the news. Another packaging is in the form of the clear and complex news content on the title that gives ease to the reader to get the information of the news. Meanwhile, in a package which does not put the clear reference on the title, the readers are suggested to continue to read the body of the news.

In a package which put the news source and its utterance on the title, the journalists juxtaposes the relation to the owner of the information. Meanwhile, in a package which put the journalists as a mediator, the readers are invited to understand the content of the news based on their understanding and interpretation. As a commodity, any packages are utilized so that the news papers are not left behind by the readers. In a news which contains local value, the local utterances are maintained for the readers from other area to learn. Finally, in the package of the news content, the selection of the news topics becomes the ideologies which are harmonized with their vision-mission.

\section{REFERENCES}

Baryadi, I. Prapomo. (2007). "Urutan Klausa dalam Kalimat Subordinatif Bahasa Indonesia." Humaniora: Jurnal Budaya, Sastra, dan Bahasa. Vol. 19(3): 224-231.

Fairclough, N. (1989). Language and Power. New York: Longman Group UK Limited. -. (1995). Media Discourse. London: Edward Arnold.

Folley, William A. (2007). A Typology of Information Packaging in the Clause. Cambridge.
Halliday, M.A.K. (1985). An Introduction to Functional Grammar. London: Edward Arnold.

Halliday, M.A.K \& Hasan, R. (1992). Bahasa, Konteks, dan Teks: Aspek-aspek Bahasa dan Pandangan Semiotik Sosial. Traslated by Barori Tou. Yogyakarta: Gadjah Mada University Press.

Hardiah, Mei. (2012). "Interjeksi Bahasa Indonesia." Thesis. Program Studi Linguistik. Fakultas Ilmu Budaya Universitas Gadjah Mada Yogyakarta.

Junaedhie, Kurniawan. (1999). Ensiklopedi Pers Indonesia. Jakarta: P.T. Gramedia Pustaka Utama.

Kadarisman, A. Effendi. (2005). "Relativitas Bahasa dan Relativitas Budaya". Linguistik Indonesia Jurnal Ilmiah Masyarakat Linguistik Indonesia. Vol. 23 (2): 151-170.

Kesuma, Tri Mastoyo Jati. (2005). "Realisasi Kategorial dan Semantis Fungsi Keterangan dalam Bahasa Indonesia". Humaniora: Jurnal Budaya, Sastra, dan Bahasa. Vol. 17(3): 261-276.

Kompas. (2014). Lima Media Televisi Dinilai Tidak Netral". 3 Juni 2014

Lia Marliana, N. dan Edi Puryanto. (2009). "Problematika Penggunaan Ragam Bahasa Jurnalistik pada Media Massa dan Implikasinya terhadap Pembinaan Bahasa Indonesia di Masyarakat. Diksi: Jurnal Ilmiah Bahasa, Sastra, dan Pengajarannya. Vol. 16 (2): 143-152.

Rolyna. Ifa. (2012). "Partikel dalam Bahasa Indonesia Ragam Informal". Tesis. Program Studi Linguistik. Fakultas Ilmu Budaya Universitas Gadjah Mada. Yogyakarta.

Santoso, Anang. (2012). Studi Bahasa Kritis: Menguak Bahasa Membongkar Bahasa. Bandung: Mandar Maju.

Sudaryanto. (1993). Metode dan Teknik Analisis Bahasa. Yogyakarta: Duta Wacana University Press.

Tim Pustaka Phoenix. (2009). Kamus Besar Bahasa Indonesia.Jakarta:PTMediaPustakaPhoenix. 